\title{
ÇALIŞMA YAŞAMINDA KADINLARIN KARŞILAŞTIĞI SORUNLAR ${ }^{1}$
}

\author{
Seval Öztürk ${ }^{2}$ - Muhammed Karataș ${ }^{3}$ \\ 2ORCID ID: orcid.org/0000-0002-5522-5210 \\ ${ }^{3}$ ORCID ID: orcid.org/0000-0002-2490-6531
}

\section{ÖZ}

Araştırmada, kadınların çalışma yaşamında yaşadığı sorunlar incelenmiştir. Tüik 'in işgücü istatistikleri, eğitim oranları vb. veriler kullanılarak ulusal bazda ve bölgesel olarak kadın ile ilgili genel görünüm elde edilmeye çalışılmış ve bu veriler ışığında değerlendirmeler yapılmıştır. Türkiye'de kadınlar çalışma yaşamında ikincil işgücü olarak görülmektedir. Evdeki sorumlulukları, doğurganlık, anaık, cinsiyet ayırımcılığı, kadının gelir getirici bir işte çalışmasının uygun görülmemesi, kadının çalışma yaşamına girmesi önünde engel oluşturmaktadır. Kadının çalışma yaşamına girmesi ile üstlendiği işgören rolü kadının evdeki rollerinin üstüne eklenmiştir. Kadının çalışma yaşamına dâhil olabilmesi için evdeki sorumluluklarını ailenin diğer bireyleri ile paylaşması gerekmektedir. Temizlik işleri, mutfak işleri, ince el becerisi gerektiren işlere olan yatkınlık, analıktan ötürü çocuk bakımındaki tecrübe; duygusal ve şefkatli yapı mesleklerin cinsiyete göre sınıflandırılmasının bir sebebi olarak düşünülebilir. Ayrıca doğurganlık, analık hali kadının çalışma yaşamına ara vermesini gerektirdiğinden anneler görevde yükselememekte, karar verme mekanizmalarına yönetici olarak atanamamaktadır. Eğitimde kız çocuklarının dezavantajlı konumda olması öğrenim seviyesinin daha düşük olmasına sebep olmaktadır. Düşük öğrenim seviyesinin kadınların geri planda, düşük ücretli, emek yoğun, uzun süre ayakta çalışııması gereken işlerde çalışmasına yol açmaktadır.

Anahtar Kelimeler: Kadın, Kadın Istihdamı, Cinsiyet Ayrımcılığı,

\section{Atıf için:}

Öztürk, S. ve Karataş, M. (2020). Çalışma yaşamında kadınların karşılaştığı sorunlar. HAKiş Uluslararası Emek ve Toplum Dergisi, 9(23), 103-120.

\footnotetext{
${ }^{1}$ Bu çalışma, Seval ÖzTÜRK tarafından Akdeniz Üniversitesi Sosyal Bilimler Enstitüsü'nde Prof.Dr.Muhammed KARATAŞ’ın danışmanlığında yürütülen "Kadınların Istihdam Edilmelerinde Karşılaştığı Sorunlar "Antalya Örneği" başlıklı yüksek lisans tezinden üretilmiş olup 27-30 Ekim 2019 tarihinde Antalya, Türkiye'de gerçekleştirilen II.Uluslararası Türk Dünyası Stratejik Araştırmalar Kongresi 2019'da bildirinin genişletilmiş halidir.

2 İş ve Meslek Danışmanı- IŞKUR, Antalya/Türkiye

E-posta: ozturk.seval@iskur.gov.tr

${ }^{2}$ Prof.Dr., Akdeniz Üniversitesi İktisadi ve İdari Bilimler Fakültesi Antalya/Türkiye

E-posta: mkaratas07@hotmail.com
} 


\title{
PROBLEMS WOMEN FACED IN EMPLOYMENT
}

\begin{abstract}
In this study, the problems experienced by women in working life were examined. It has been tried to obtain an overview of women on a national and regional basis by using data such as labor force statistics and education rates of TUIK. Women are seen secondary labor force in working life. Women's responsibilities at home, fertility, maternity, gender discrimination and negative attitude towards women's income- generating work create obstacles to women's labor force participation. With the participation of women in working life, their responsibilities increased. Therefore, it is necessary to share the household responsibilities with other members of the family in order to participate in working life. Women's susceptibility to cleaning, kitchen work, manual dexterity, experience in child care due to maternity and emotional and compassionate structure may be considered as a reason for the classification of occupations by gender. In addition, since fertility and maternity require women to take a break from working life, mothers cannot move up to an executive position and cannot be appointed as manager for decision-making mechanisms. The disadvantage of girls in education leads to lower levels of education. The low level of education leads women to work in the background, in low paid job, labor intensive and long-standing jobs.
\end{abstract}

Keywords: Women, Women's Employment, Classification of Occupations by Gender. 


\section{GíRiş}

Toplumumuzda kadınların öncelikle evin işleyişinden sorumlu olduklarına dair bir düşünce vardır. Temizlik, yemek, ütü, çocuk bakımı, hasta bakımı, vb. ev içi işler kadın işi; gelir getirici bir işte çalışma, alışveriş vb. dışarı işleri erkek işleri olarak algılanmaktadır. Kadınların evdeki sorumlulukları iş yaşantısına da yansımaktadır. Kadın çalışma yaşamına girerek sahip olduğu iş gören rolü ve sorumlulukları kadının evdeki anne, eş, ev hanımı olmasının getirdiği sorumluluklarının üstüne eklenmektedir. Kadın bu sorumlulukları ailenin diğer üyeleri ile paylaşabildiği oranda çalışma yaşamına tutunabilmektedir. Kişinin kendi gelirini elde edebiliyor olması, yeni bir sosyal çevresinin oluşması vb. kazanımlar kadınların öz güvenini desteklemekle beraber ailenin refah düzeyini de yükseltmektedir.

Kadınların evdeki sorumlulukları nedeniyle iş-aile dengesini kuramaması, kadının çalışmasının uygun olmadığına dair geleneksel önyargılar, eğitime erkekler kadar rahat ulaşamama, göç etkisi, kadının ikincil işgücü olarak düşünülmesinden ötürü ucuz işgücü olarak görülmesi, doğurganlık, analık hali, vb nedenler kadının işgücüne katılımını zorlaştırırken, işgücüne katılmış olan kişiyi de işinden koparabilmektedir.

\section{ÇALIŞMA YAŞAMINDA KADIN}

II. Dünya Savaşı sonrası hizmet sektörünün gelişmesi ve kadınların bu sektöre uygun olmaları kadın istihdamını arttırmıștır. Kadının üstlendiği bu yeni rol evdeki rollerinin üstüne eklenmiştir ve kadının üstündeki yük artmıştır. Ülkemizde kadınlar 1950'li yıllar itibariyle çalışma yaşamına aktif olarak girmeye başlamıștır. Fakat toplumsal olarak ikinci planda görülen kadın, ekonomik olarak da ikinci planda kalmış ve kadının geliri, erkeğin gelirine ek bir gelir olarak kabul edildiği için; ucuz işgücü olarak görülmüştür. Ayrıca Kocaclk ve Gökkaya (2005, s.199); işgücü maliyetlerinin düşürülebilmesi için işgücünün merkez ve çevre olarak ele alındığı, merkezde işü̈cünü erkeklerin, çevrede ve aralarda ise kadınların istihdam edildiğine dikkati çekmektedir. Kadın toplumsal yaşamda ikincil rollerde görüldüğü gibi çalışma yaşamında da ikincil işgücü olarak görülmektedir. Bu düşünce kadının çalışma yaşamında işten çıkartılmada tercih edilecek ilk kişi, düşük ücretle çalıştırılabilecek işçi olarak algılanmasına sebep olmaktadır.

"Pek çok toplumda meslekler yatay olarak katmanlaşarak "kadın işi" ve "erkek işi" olarak ikiye ayrllırlar. Genel olarak "kadın işi" düşük statülü ve ücretli, geçici, güvencesiz olan niteliksiz işlerden, buna karşı "erkek iși" yetki ve sorumluluk gerektiren, yüksek ücretli, sürekli, güvenceli olan nitelikli işlerden oluşmaktadır" (Parlaktuna, 2010, s.1222). Yaraman'a göre de ucuz emek kadınların kamusal alana çıkışının önemli nedenlerinden biridir. Yaraman; ucuz emek talebinin çalışma yaşamına çektiği kadınlar hem nitelikli işgücü oluşturmak hem de 
nitelikli işgücü yetiştirmek, toplumsal anneliği daha iyi ifa etmek için eğitime yönelmiş ve yönlendirilmiş olduklarını belirtmiştir (http://www.aysegul-yaraman.com/makale/ya-nilsamanin_neresindeyiz.pdf).

Türkiye'de göç etkisi ile kırsaldan ayrılan kadınlar istihdama katılmada güçlük yaşamaktadır. Kırsalda tarım işçisi olan, ücretsiz aile işçisi olan kadın, çalışma yaşamından uzak kalmıştır. Toplumda kadının çalışmasını uygun görmeyen geleneksel görüş ile kadının çalışmasının ailenin yoksul olduğunu çağrıștırması düşüncesi onların çalışmasının önünde engel olmuştur. Kadına; kadının doğurganlığına atıf yaparak, onu ailenin şefkat merkezine koyup, kutsallaştırarak kadının yerinin evi; görevinin eşine, çocuklarına varsa aile büyüklerine bakması olduğu öğretilmiştir. Kadınlar çalışma yaşamına girdiklerinde ev yaşantılarındaki rutin işleyişi de devam ettirmek zorundadır. Toplumsal algı; ev işleri, çocuk-yaşlı bakımı vb. işleri kadına ait işler olarak görmektedir. Kadınlara göre bu değiştirilemeyen sosyal bir durumdur.

Tablo 1. İsgücüne Dâhil Olmayanların Yıllara Göre İşǘcüne Dâhil Olmama Nedenleri İşgücüne dâhil olmayanların yıllara göre işgücüne dâhil olmama nedenleri İş aramayıp, çalışmaya hazır olanlar

\begin{tabular}{|c|c|c|c|c|c|c|c|c|c|}
\hline 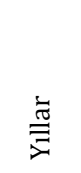 & $\begin{array}{l}\text { ह } \\
\frac{\pi}{2} \\
\frac{0}{0} \\
\bullet\end{array}$ & 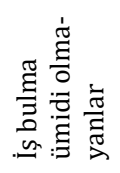 & 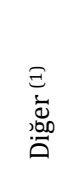 & 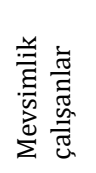 & 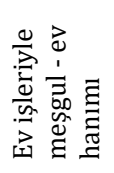 & 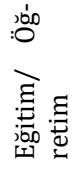 & 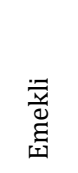 & 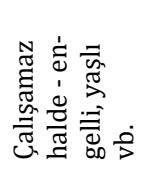 & 芯 \\
\hline 2014 & 28200 & 615 & 1869 & 94 & 11589 & 4470 & 3827 & 3922 & 1814 \\
\hline 2015 & 28176 & 676 & 1726 & 94 & 11498 & 4486 & 4082 & 3878 & 1736 \\
\hline 2016 & 28185 & 658 & 1762 & 89 & 11098 & 4541 & 4160 & 4036 & 1843 \\
\hline 2017 & 28251 & 637 & 1627 & 85 & 11133 & 4467 & 4366 & 4009 & 1926 \\
\hline 2018 & 28380 & 546 & 1624 & 155 & 11061 & 4472 & 4536 & 4040 & 1944 \\
\hline
\end{tabular}

* Diğer: Mevsimlik çalışma, ev kadını olma, ögrencilik, irad sahibi olma, emeklilik ve çalışamaz halde olma gibi nedenlerle iş aramayıp ancak işbaşı yapmaya hazır Kaynak: TÜIK, İsgücü İstatistikleri - 2018

Tablo 1'de işgücüne dâhil olmayanların yıllara göre işü̈cüne dâhil olmama nedenleri incelendiğinde; 2018 yılında işgücüne dâhil olmayan 28380 kişiden 11061 kişisi ev kadınıdır. Yıllar bazında bakıldığında ev işleriyle meşgul - ev hanımlarının sayısının 2014 yılına göre 2018 yılında düştügü görülmektedir. Türkiye'de göç etkisi ile kırsaldan ayrılan kadınlar öncelikle, ev hanımı olmayı tercih etmiştir. Kırsalda tarım işçisi olan, ücretsiz aile işçisi olan kadın, çalışma yaşamından uzak kalmıştır.

TÜIKK verilerine göre 2018 yllında işgücüne dâhil olmayanların \%38,7'sinin bakım sorumluluğu bulunurken erkeklerde bu oran \%14,8, kadınlarda ise \%45,9 olmuştur (http://www.tuik.gov.tr/PreHaberBul-tenleri.do?id=30707). Bu veri kadınların işe dâhil olamayıp ücretsiz ev işçisi olarak çalıştıklarının göstergesi olarak kabul edilebilir. Bu veri sadece evli olan, bakmayla yükümlü 
olduğu çocuğu olan kadınları akla getirmemelidir. Bu oran içinde öğreniminden ayrılmak zorunda kalan ya da bir üst öğrenim kurumuna kayit yaptıramayan genç kadınlar bulunmaktadır. TÜiK' e göre ne eğitimde ne istihdamda olan gençlerin oranı genç erkeklerde \%15,6, genç kadınlarda ise \%33,6'dır (http://www.tuik.gov.tr/PreHaberBul-tenleri.do?id=30723).

Tablo 2. Türkiye 2018 Yılı İsgücüne Katılım Oranları

\begin{tabular}{lll}
\hline & Cinsiyet & Oranlar \\
\hline İşücüne Katılma Oranı (\%) & Erkek & 78,6 \\
& Kadın & 38,3 \\
\hline
\end{tabular}

Kaynak: TÜiK, İsgücü İstatistikleri - 2018

Tablo 2 incelendiğinde erkeklerin işgücüne katılım oranının kadınların işgücüne katılım oranının iki katından daha fazla olduğu aşikardır.

Tablo 3. Türkiye 2018 Yılı İssizlik Oranları

\begin{tabular}{lll}
\hline & Cinsiyet & Oranlar \\
\hline İşsizlik Oranı (\%) & Erkek & 9,7 \\
& Kadın & 14,2 \\
\hline
\end{tabular}

Kaynak: TÜIK, İsgücü İstatistikleri - 2018

İşsizlik oranlarının verildiği Tablo 3 incelendiğinde kadınların işsizlik oranının erkeklerin işsizlik oranından oldukça fazladır.

Türkiye'de çalışma yaşamında kadınlar istihdam edilmekte sorun yaşadıkları için istihdam oranları erkeklere göre oldukça düşüktür. TÜİK 2018 verilerinde erkek nüfusunu 41 milyon 139 bin 980 kişi, kadın nüfusunu 40 milyon 863 bin 902 kişi olarak açıklamıştır. İşgücüne katılan kadın ulusal düzeyde ekonomiye katkı olmakla birlikte aile gelirinin artmasına katkısı olacağından ailenin refah düzeyinin arttırılmasına katkı sağlayacaktır.

Tablo 4 'te Türkiye'de bölgeler arası gelişmişlik düzeyindeki farklılıklar kadın istihdam oranına belirgin şekilde yansımaktadır. Kadınların işgücüne katılım oranlarının en düşük olduğu düzey bölgeleri Doğu ve Güneydoğu Anadolu Bölgeleri'ndedir. Bu bölgelerde kadın işsizlik oranları da diğer bölgelere göre yüksektir. Bu bölgelerdeki geleneksel bakış açısı kadınların çalışması önünde bir engel oluşturmaktadır. Ayrıca bölgede iş olanağının az oluşu kadınları işgücü piyasasına girişini zorlaştırmaktadır. Önder (2013: 44), yapılan araştırmalarda göç eden kadınların, yerli kadın işçiye göre; göç eden kadınların, göç eden erkeklere göre daha dezavantajlı konumda olduğunu ifade etmektedir. 
Tablo 4. 2018 Yılı Türkiye’de Düzey Bölgelerine Göre İşgücüne Katılım ve İşsizlik Oranları

\begin{tabular}{|c|c|c|c|c|}
\hline \multicolumn{5}{|c|}{ Bölgelere Göre İşgücüne Katılım ve İşsizlik Oranları (+15 yaş) } \\
\hline & \multicolumn{2}{|c|}{ Erkek } & \multicolumn{2}{|c|}{ Kadın } \\
\hline & 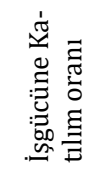 & 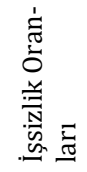 & 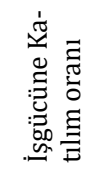 & 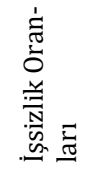 \\
\hline Kastamonu, Çankırı, Sinop-TR82 & 70,2 & 3,7 & 43,5 & 7,1 \\
\hline Aydın, Denizli, Muğla-TR32 & 71,9 & 5,2 & 42,2 & 9,6 \\
\hline Antalya, Isparta, Burdur-TR61 & 72,9 & 9 & 40,7 & 16,3 \\
\hline Trabzon, Ordu, Giresun, Rize, Artvin, Gümüșhane-TR90 & 69,4 & 5,8 & 40,4 & 6,8 \\
\hline Tekirdağ, Edirne, Kırklareli-TR21 & 78,9 & 5 & 40 & 12,5 \\
\hline Samsun, Tokat, Çorum, Amasya-TR83 & 71,2 & 5,6 & 39,9 & 7,8 \\
\hline İzmir-TR31 & 74,1 & 10,8 & 38,7 & 19,3 \\
\hline İstanbul-TR10 & 77,1 & 10,9 & 37,9 & 15,5 \\
\hline Manisa, Afyonkarahisar, Kütahya, Ușak-TR33 & 72,3 & 5,7 & 35,9 & 9 \\
\hline Bursa, Eskişehir, Bilecik-TR41 & 70,7 & 6,9 & 35,2 & 13,1 \\
\hline Zonguldak, Karabük, Bartın-TR81 & 66,4 & 5,9 & 34,2 & 12 \\
\hline Türkiye-TR & 72,7 & 9,5 & 34,2 & 13,9 \\
\hline Kocaeli, Sakarya, Düzce, Bolu, Yalova-TR42 & 75,2 & 8,4 & 34 & 14,3 \\
\hline Malatya, Elazı̆̆, Bingöl, Tunceli-TRB1 & 71,7 & 7 & 33,8 & 10,1 \\
\hline Ankara-TR51 & 72,5 & 8 & 32,8 & 14,7 \\
\hline Kırıkkale, Aksaray, Niğde, Nevşehir, Kırşehir-TR71 & 71,5 & 8,3 & 32,6 & 16,5 \\
\hline Balıkesir, Çanakkale-TR22 & 66,1 & 4,2 & 32,6 & 8,7 \\
\hline Adana, Mersin-TR62 & 69,2 & 9,8 & 31,9 & 14,3 \\
\hline Ağrı, Kars, Iğdır, Ardahan-TRA2 & 68,8 & 5,5 & 31,1 & 4,7 \\
\hline Hatay, Kahramanmaraş, Osmaniye-TR63 & 70,2 & 12 & 29,8 & 18,7 \\
\hline Konya, Karaman -TR52 & 72,8 & 5,3 & 29,8 & 7,3 \\
\hline Erzurum, Erzincan, Bayburt-TRA1 & 69,4 & 7,6 & 27,6 & 7,3 \\
\hline Kayseri, Sivas, Yozgat-TR72 & 70,4 & 10,8 & 26,4 & 19 \\
\hline Şanlıurfa, Diyarbakır-TRC2 & 72 & 18,7 & 25 & 18,6 \\
\hline Van, Muş, Bitlis, Hakkâri-TRB2 & 73 & 22 & 24,4 & 20 \\
\hline Gaziantep, Adıyaman, Kilis-TRC1 & 71,8 & 12,8 & 21,9 & 12,5 \\
\hline Mardin, Batman, Şırnak, Siirt-TRC3 & 65,7 & 22,6 & 17,8 & 33,2 \\
\hline
\end{tabular}
Kaynak: TÜIK, İsgücü İstatistikleri - 2018

İşsizlik oranlarının İzmir (\%19), İstanbul (\%16), Antalya (\%16), Ankara (\%15), Adana (\%14), Mersin (\%14) gibi sosyo-ekonomik açıdan daha gelişmiş şehirlerde Türkiye ortalamasının üstünde olmasının göç etkisinden kaynaklandığı ifade edilebilir. Kırsalda eğitim düzeyi düşük olan, ücretsiz aile işçisi olarak tarım ve hayvancılık işlerinde çalışan kadınlar şehirde kendilerine uygun iş bulamamaktadırlar. Göç eden kadınlar genellikle ev hizmetlerinde ucuz işgücü olarak kayıt dışı çalışmaktadır. Kadınların ücretsiz aile işçisi olarak çalışmaları ya da sosyal güvencesiz olarak kayıt dışı çalışmaları onları, sosyal haklarına ulaşmalarının önünde engel oluşturmaktadır. Kişilerin ekonomik özgürlükleri kısıtlanmakta; kişiler emeklilik hakları ve sağlık güvencelerinden mahrum kalmaktadırlar.

Çalışmanın zaruri olduğu düşük gelirli ailelerde kadın eşinin, babasının, abisinin onayını alarak çalışma yaşamına dâhil olabilmiştir. İşin ve iş ortamının seçilmesi yine ailede bulunan erkeklerin uygun bulduğu yerler arasından 
yapılmaktadır. Kadının çalışmasına yönelik bu tutumlar çalışma yaşamında kadını, erkeğin bir adım gerisinde bırakmıștır. Türkiye'de çalışan kadınların büyük bir oranı çalışma yaşamına kariyer yapmaktan ziyade aile bütçesine katkı sağlamak için katılmaktadır. Kadının aileye sağlayacağı katkının çocukların kreş - bakıcı masrafı, ailedeki bakıma muhtaç hasta ve yaşlı kişinin bakıcı masrafı, ev işlerinde yardımcı olacak ev işçisinin ücreti, kadının işe gideceği yol ücreti ve işyerindeki yemek masrafının üstünde olması durumunda çalışması kabul görmektedir. Kadının kazandığı para bu giderleri karşılamıyor ya da sonuçta kadının elinde kabul edilebilir bir miktar para kalmıyorsa "kadın evinde işini yapsın, bu giderler oluşmasın" düşüncesi oluşmaktadır. Erkek ve Karagöz (2009); ekonomik nedenlerle ya da başka bir nedenle çalışma yaşamına giren kadınların ekonomik özgürlüklerini elde ettiklerini belirtmişlerdir. Ayrıca bu ekonomik özgürlük kadına özgüven sağlamıştır. Ailede ekonomiye katkısı olan kadın, söz hakkı alarak karar mekanizmalarına katılmaktadır. Ayrıca kadının gelir getirici bir işte çalışması, toplumda kadına olan bakış açısını kadının lehine olacak şekilde değişmesine olanak tanımıştır. Ekonomik sebeplerle çalışma yaşamına katılan kadın, çalışmanın toplumsallaşmayı da desteklediğini görmüştür.

Kadınlar çalışma yaşamında ve eğitimde ikincil olarak düşünülmektedir. $\mathrm{Bu}$ durumun tarihi yeni değildir. Demiryontan ve Savran (2016); "Kadının Görünmeyen Emeği" kitabında avcı -toplayıcı dönemde gruplar halinde yaşayan insanların bir arada hareket ettikleri ve sık sık yer değiştirdiklerini, kadın ve erkeğin eşit sayıldığını; avcı- toplayıcı toplumdan bitki yetiştirilmesiyle yerleşik hayata geçildiğini, üretim yoğunlaştıkça da iş bölümünün cinsiyete göre farklılaştığını belirtmişlerdir. Tarımsal üretime ve yerleşik hayata geçilmesiyle kadının erkekle birlikte hareketinin kısıtlanmaya başladığı; avın sürekli takip edilmek zorunda olması, yaşam alanından uzakta kalma durumunun olması anneye ihtiyacı olan çocuk olması ya da hamile bir kadının bu riski alamayacak olmasından ötürü; erkeklerin bu duruma daha uygun olduğunun düşünüldüğ̈̈ne kitapta yer verilmiştir. Ayrıca avcı-toplayıcı toplumdan tarım toplumuna geçişle beraber toplumun yapısı kökten değişime uğrayarak toplumsal cinsiyete dayalı bir iş bölümü ortaya çıktığı, iş bölümündeki sınıflandırmanın bir cinsiyetin öbür cinsiyeti katı bir şekilde ezen bir sistemin oluşmasına neden olduğunu ifade etmişlerdir. Kadının doğurganlık ve analık durumu; kadını evinde çocuk bakma, tarlasıyla ilgilenme görevleri ile sınırlandırmaya başladığını belirtmişlerdir.

Sautet (1998) "Kadınların Özgürleşmesi Üzerine" kitabında; Aristoteles'in diğer bütün türlerde olduğu gibi insanlarda da erkeğin dişiden güçlü olduğu görüşüne vurgu yapmıştır. Ayrıca Spinoza'nın kadınların doğaları gereği olarak kadınların kocalarının hâkimiyeti altında olması gerektiğini, kadınların hükümdar değil uyruk olmasını savunduğunu belirtmiştir.

Berktay'a (2015) göre Eski Mezopotamya'da yazının- kayıt tutma bilgisinin- erkek olan rahip, vakanüvis, akademik aydınların elinde olması kayıtla- 
rın erkekler lehine yazılarak kadınların yok sayılmasına sebep olmuştur. Kadınlar eş - anne rolünde kutsallaştırılmış, olumlu davranışlar bu rollerle bağdaştırılmıştır. Bu rollerin dışına çıkan kadınlar toplumdan dışlanarak cezalandırılmış, diğer kadınların bu cezalandırılmayı göz önünde bulundurarak, davranışlarını bu doğrultuda şekillendirilmesi amaçlanmıştır. Binlerce yıldır ataerkil sistem içinde yaşayan kadın kendine yakıştırılan rolleri benimsemişbenimsemek zorunda kalmıș, sorgulamaktan çekinmiştir. Hatta kadının kendisi kendi aleyhine olan toplumsal cinsiyet algısını benimsemiş ve destekçisi olmuştur. Ailede kız çocuk, erkek çocuğun sofrasını kurmuş, kıyafetlerini giyilmeye hazır hale getirmiş, ev işlerinde anneye yardım etmiştir. Kız çocuğa ileride eşine de aynı hizmeti vermesi, kendi kız çocuğunu da bu doğrultuda yetiștirmesi salık verilmiştir. Toplumumuzda "Anasına bak kızını al, kenarına bak bezini al." atasözü kullanılmaktadır. Kızların kendine yakıștırılan rolleri ne derece benimsediğini annesine bakılarak az çok anlaşılabileceğini atasözlerimizde bile yer bulmuştur. Geleneksel yapıya dayalı düşüncede olan annelerin kız ve erkek çocuklarına yönelik farklı tutumları buna örnek gösterilebilir.

Çalışma yaşamında kadının nitelikli işlerde istihdam olmasına engel olan nedenlerden biri de eğitimdir. Ülkemizde kız çocukları eğitim imkânına erkekler kadar rahat ulaşamamaktadır. Kız çocukların eğitimde kalma süreleri erkeklerden daha azdır. Özellikle kırsal bölgelerde zorunlu eğitim süresi olmasına rağmen belirgin șekilde kızlar eğitimden uzak kalmakta ya da eğitimden bir süre sonra koparılmaktadırlar. Kız çocukların eğitime katılımının düşük olduğu bölgelerde ailelere ev ziyaretleri düzenlenerek bilgilendirme çaıışmaları yapılmasına rağmen kız çocukları eğitime dâhil edilememektedir.

\section{Tablo 4. Eğitimden Erken Ayrılanların Yıllar ve Cinsiyete Göre Durumu}

\begin{tabular}{ccc} 
YILLAR & $\begin{array}{c}\text { Toplam Erkek Nüfus İçinde 18 - 24 } \\
\text { Yaş Aralığında Eğitimden Ayrılan- } \\
\text { lar (\%) }\end{array}$ & $\begin{array}{c}\text { Toplam Kadın Nüfus İçinde 18 }-24 \\
\text { Yaş Aralığında Eğitimden Ayrlanlar } \\
(\%)\end{array}$ \\
\hline 2014 & 35 & 40,9 \\
2015 & 35,4 & 37,9 \\
2016 & 32,7 & 35,9 \\
2017 & 31,1 & 34 \\
\hline
\end{tabular}

Kaynak: TÜiK, İşgücü İstatistikleri- 2018

Tablo 5 incelendiğinde; 2017 yılında 18- 24 yaș arasında eğitimden ayrllan kadınların toplam kadın nüfusu içindeki oranı \%34 iken, erkeklerde bu oran \%31,1'dir. Bu bilgiye istinaden kadınların eğitimden daha fazla oranla koptukları veya koparıldıkları söylenebilir. Yıllar bazında incelendiğinde oranların her geçen yıl düştüğü görülmektedir. Baba Beni Okula Gönder, Haydi Kızlar Okula, Kız Çocukların Okullaşma Oranının Arttırılması Projesi, Hedef 10.000 Kızımızı Okula Döndürmek, Canım Kızım Okulda, Okula Devam Projesi, Kardelenler Projesi vb. projeler ile kız çocuklarının eğitimi desteklenerek eğitimden erken ayrılma oranlarının düşürülmesi hedeflenmektedir. 
Tablo 5. Düzey Bölgelerinde Eğitim ve Cinsiyete Göre İsggücü İstatistiği (Bin Kişi)

\begin{tabular}{|c|c|c|c|c|c|c|c|c|}
\hline & \multicolumn{2}{|c|}{$\begin{array}{l}\text { Okuma Yazma } \\
\text { Bilmeyen }\end{array}$} & \multicolumn{2}{|c|}{$\begin{array}{l}\text { Lise Altı Eği- } \\
\text { timliler }\end{array}$} & \multicolumn{2}{|c|}{$\begin{array}{c}\text { Lise ve Dengi } \\
\text { Meslek } \\
\text { Okulu }\end{array}$} & \multicolumn{2}{|c|}{$\begin{array}{c}\text { Yüksek Öğre- } \\
\text { tim }\end{array}$} \\
\hline & Erkek & Kadın & Erkek & Kadın & Erkek & Kadın & Erkek & Kadın \\
\hline Adana, Mersin-TR62 & 19 & 21 & 537 & 213 & 235 & 105 & 190 & 136 \\
\hline Ankara-TR51 & 8 & 8 & 609 & 215 & 422 & 142 & 453 & 332 \\
\hline Antalya, Isparta, Burdur-TR61 & 5 & 13 & 437 & 230 & 208 & 86 & 189 & 141 \\
\hline Aydın, Denizli, Muğla-TR32 & 3 & 15 & 476 & 260 & 181 & 86 & 151 & 130 \\
\hline Ağrı, Kars, Iğdır, Ardahan-TRA2 & 8 & 33 & 170 & 53 & 38 & 8 & 28 & 12 \\
\hline Balıkesir, Çanakkale-TR22 & 3 & 7 & 226 & 122 & 102 & 38 & 97 & 57 \\
\hline Bursa, Eskișehir, Bilecik-TR41 & 11 & 14 & 530 & 243 & 305 & 114 & 239 & 172 \\
\hline Erzurum, Erzincan, Bayburt-TRA1 & 4 & 12 & 125 & 52 & 67 & 11 & 56 & 27 \\
\hline Gaziantep, Adıyaman, Kilis-TRC1 & 11 & 19 & 425 & 86 & 119 & 33 & 100 & 63 \\
\hline Hatay, Kahramanmaraș, Osmaniye-TR63 & 21 & 40 & 456 & 176 & 159 & 54 & 116 & 69 \\
\hline Kastamonu, Çankırı, Sinop-TR82 & 2 & 9 & 104 & 74 & 47 & 14 & 35 & 25 \\
\hline Kayseri, Sivas, Yozgat-TR72 & 3 & 16 & 339 & 117 & 147 & 37 & 113 & 67 \\
\hline Kocaeli, Sakarya, Düzce, Bolu, Yalova-TR42 & 5 & 14 & 558 & 225 & 302 & 94 & 211 & 143 \\
\hline Konya, Karaman -TR52 & 5 & 14 & 386 & 157 & 109 & 32 & 107 & 60 \\
\hline Kırıkkale, Aksaray, Niğde, Nevșehir, Kırșehir-TR71 & 5 & 11 & 223 & 104 & 92 & 27 & 69 & 47 \\
\hline Malatya, Elazığ, Bingöl, Tunceli-TRB1 & 8 & 32 & 217 & 100 & 109 & 27 & 91 & 51 \\
\hline Manisa, Afyonkarahisar, Kütahya, Uşak-TR33 & 5 & 24 & 476 & 237 & 190 & 63 & 144 & 94 \\
\hline Mardin, Batman, Şırnak, Siirt-TRC3 & 13 & 23 & 273 & 53 & 83 & 22 & 79 & 33 \\
\hline Samsun, Tokat, Çorum, Amasya-TR83 & 11 & 50 & 411 & 230 & 150 & 50 & 117 & 79 \\
\hline Tekirdağ, Edirne, Kırklareli-TR21 & 5 & 8 & 286 & 133 & 135 & 54 & 102 & 72 \\
\hline Trabzon, Ordu, Giresun, Rize, Artvin, Gümüșhane-TR90 & 3 & 40 & 349 & 214 & 160 & 62 & 133 & 84 \\
\hline Van, Muș, Bitlis, Hakkari-TRB2 & 15 & 42 & 335 & 74 & 84 & 20 & 61 & 27 \\
\hline Zonguldak, Karabük, Bartın-TR81 & 1 & 9 & 132 & 76 & 66 & 17 & 48 & 32 \\
\hline İstanbul-TR10 & 31 & 52 & 2279 & 817 & 1026 & 462 & 1110 & 887 \\
\hline İzmir-TR31 & 7 & 19 & 619 & 252 & 291 & 130 & 303 & 262 \\
\hline Șanlıurfa, Diyarbakır-TRC2 & 34 & 84 & 529 & 114 & 134 & 36 & 101 & 60 \\
\hline
\end{tabular}

Kaynak: TÜiK, İsgücü İstatistikleri - 2018

TÜİK raporuna göre Türkiye'de 2017 yılında, 25 ve daha yukarı yaşta olan ve en az bir eğitim düzeyini tamamlayanların oranı erkekler için \%95,5 iken bu oran kadınlarda \%83,6'dır (http://www.tuik.gov.tr/PreHaberBul-tenleri.do?id=30707). Tablo 6 incelendiğinde herhangi bir öğrenim seviyesinde eğitim almış kişilerde bütün satırlarda kadınların sayısı erkeklerden daha düşüktür. Bu tablodan kadınların bir eğitim kurumuna bağlı olarak öğrenim alması konusunda dezavantajlı olduğu, öğrenimlerine devam edemedikleri ya da eğitimden kopmak zorunda kaldıkları söylenebilir. Okuma yazma satırına bakıldığında; kadınların her ilde erkeklere göre daha yüksek sayılarda olduğu görülmektedir. Genel olarak Türkiye'de okuma yazma bilmeyen kadın sayısının erkek sayısından daha yüksek olduğu, herhangi bir seviyede eğitim almış kadın sayısının erkek sayısından daha düşük olduğu Tablo 6 'da görülmektedir.

UNICEF, ülkemizde kız çocukların okullaşma oranını, okulların bulunduğu bölgeye ulaşımdaki zorlukların, fiziksel şartların yetersiz olması, ailelerin ekonomik durumları ve geleneksel önyargıların etkilediğini bildirmiștir.

Okulların merkez bölgelerde toplanmış olması, okula ulaşım için belli bir mesafeyi aşmak, servis kullanımı, kışın yol durumunun ulaşımı zorlaştırması gibi nedenler kız çocuklarının bu zorluğu aşmaya uygun görülmemesine neden olmaktadır. Kırsal bölgelerde ilk 4 yıllık eğitime ulaşmak zor olmasa bile ikinci 4 yıllık eğitim için büyük çoğunlukta taşımalı olarak bölgedeki büyük bir köye ya da en yakın ilçeye; lise okumak isteyen bir genç en yakın ilçeye ulaşmak zorundadır. Genellikle aileler kız çocuklarını kendilerinden uzakta 
olmasını istememektedirler. Bu durum kız çocukların büyük çoğunluğunun eğitimden kopmasına neden olmaktadır.

Devlet okullarında dahi belli bir kırtasiye masrafı olması, ulaşım gideri, öğle yemeği gideri, aileleri ekonomik olarak zorlamaktadır. Ekonomik olarak gider olan eğitim/okul masraflarını karşılamak yerine kız çocuklarını kendi hesabında ücretsiz işgücü olarak kullanmak ya da ücret karşılığı bir yerde çalıştırmak ailelere daha cazip gelmektedir. Kırsalda; geleneksel aile yapısında kızlar eğitimlerini tamamlayıp gelir getirici bir mesleğe sahip olsalar bile ailelerine bir katkı sağlayamayacağı, artık kendi yeni bir ailesi olması düşüncesi kızların eğitimi önünde engeldir. Ayrıca geleneksel görüş; aileleri kız çocuklarını 16 - 24 yaş arasında evlendirmeye yönlendirmektedir.

Özsoy'a (2003, s.2) göre Türkiye'de eğitimsizlik, dini değerler gibi nedenlerle kadınların öğrenim süreleri çok yetersizdir. Kadınların eğitimsiz olması onları uzun saatler boyunca ayakta kalmayı, devamlı hızlı hareket etmelerini gerektiren, vardiyalı çalışma sistemi olan emek yoğun işlerde çalışmaya mecbur kılmaktadır. Ayrıca kadınlara çalışma saatleri ve ortamları açısından kendilerini daha güvende hissetmeleri, kendilerinin aile yaşantılarını olumsuz etkilememesi, biyolojik ve toplumsal olarak oluşturulan rollere uygun olması açısından bazı meslekler yakıştırılmıştır. Bu durum hemşirelik, öğretmenlik, sekreterlik, büro memuru gibi mesleklerin kadın mesleği olarak görülmesine neden olmuştur. Hatta bazı ülkelerde sekreterlik, hemşirelik gibi mesleklerde erkeklerin bu mesleğe mensup olmalarına sıcak bakılmamaktadır. Kadınların iş hayatına girmesiyle erkeklerin yaptığı birçok işi kadınlar yapmaya başlamış, işgücü piyasası kadınlara göre şekillenmeye başlamıştır. Önder'e (2013, s.49) göre; kadının işgücü piyasasına bağımsız şekilde girmesini sağlayan en önemli unsur eğitimdir. Eğitim arttıkça işin değeri ve ücreti artmaktadır.

Mesleklerin cinsiyete göre sınıflandırılması kadınları çalışma yaşamında belli mesleklere yönelmesini zorunlu kılmaktadır. Kadınlar toplumun kendilerine yakıştırdıkları aile içi roller, meslek rolleri ile sınırlandırılmaktadır. Aileler günümüzde dâhi erkek çocuklarının yükseköğrenimi için düşündükleri ya da planladıkları bölümlerin kız çocukları için uygun olmadığını düşünmektedirler.

Ataerkil toplumda kadın erkeğin idaresine tabii bir şekilde ve toplumca da kabul edilen kurallara göre yaşamaktadır. Foucault' a (2007, s.367) göre İ.Ö. IV. ya da III. yüzyıldan kalma belgelerde, kadının görevlerinin kocaya itaati, gündüz ya da gece kocanın izni olmaksızın dışarı çıkma yasağını, hanesini yoksullaştırma ve kocasının onuruna halel getirme yasağını kapsadığı görülür. Ayrıca Foucault (2007, s.367) erkeğe kadının gereksinimlerini yerine getirme, karısına bakma görevi verildiğini belirtmiștir. Bu durum kadının zayıf olduğunun, bir başkası tarafından bakılması gerektiğinin toplumca kabul edildiğinin göstergesidir. 
Kadınlar çocukluk döneminden itibaren annelik, temizlik, yemek gibi sorumluluklarla yetiştirilmektedir. Kız çocuklarının oyuncaklarının bebek, yemek seti, temizlik malzemesi olması, bir araya geldiklerinde evcilik oynamalarl; erkek çocuğun da kız çocuğun bu şekilde büyütüldüğünü görmesi ve bu durumu annesinin yaşantısı ile ilişsilendirerek büyümesi toplumda kadın erkek rollerinin belirleyicisi olmaktadır. Toplumda kadının temizlik, bakım, ev işlerine yatkın olduğu, analık görevlerinin olduğu, çalışmaya uygun olmadıkları algısı oluşmaktadır. Bu algının mesleklerin cinsiyete göre sınıflandırılmasına; çalışma sisteminin ve şeklinin belirlenerek kadının sınırlandırılmasına, kadınların çalışma hayatına dâhil olamamasına sebep olduğu söylenebilir. Platon Devlet kitabında erkek ve kadınlara fitratlarına göre iş verilmesi gerektiğini; hekimlik fitratı olan kadının hekim, marangozluk fitratı olan erkeğin marangoz olması gerektiğini belirtmiştir. Platon kadın ve erkeklere aynı eğitimin verilmesini, kişinin kendi doğasında olan işi yapmasını savunur.

Kadınlara çalışma yaşamında bazı mesleklerin yakıştırılması ve kadınların belli mesleklerle sınırlandırılması onların belli bir sosyal statüde kalmalarına sebep olmaktadır.

"Toplumda egemen cinsiyetçi ideolojiye göre, kadının yeri evi, hayatındaki asli görevi de ev işi yapmak, kocasına ve çocuklarına bakmaktır. Bu da, genellikle evdeki işlerin uzantısı olan mesleklerde ve çalışma alanlarında istihdam edilmesine yol açmaktadır. Kadın, kendine benimsetilen toplumsal cinsiyete göre, küçük yaştan itibaren kendine belletilen düşünce ve davranış kalıplarına göre bir takım ediniyor ve çalışma yaşamına girince de bu becerilerin uzantısı alanlarda çalıştırılıyor. Hizmet, sağlık, eğitim ya da hazır giyim sektörlerinde daha yoğun olarak istihdam edilmeleri bu yüzdendir" (Ansal,1996, s.55).

Tablo 6. Aranılan Meslek Grubuna Göre İșsizler

\begin{tabular}{llccccc}
\hline & Cinsiyet & 2014 & 2015 & 2016 & 2017 & $\begin{array}{c}2018- \\
\text { Aralık }\end{array}$ \\
\hline Yöneticiler & Erkek & 50 & 41 & 48 & 44 & 56 \\
& Kadın & 15 & 15 & 13 & 18 & 21 \\
\hline Profesyonel meslek mensupları & Erkek & 122 & 135 & 171 & 184 & 226 \\
& Kadın & 170 & 210 & 244 & 311 & 315 \\
\hline Teknisyenler, teknikerler ve yardımcı pro- & Erkek & 106 & 116 & 137 & 146 & 154 \\
fesyonel meslek mensupları & Kadın & 98 & 104 & 117 & 125 & 143 \\
\hline Büro ve müşteri hizmetlerinde çalışan & Erkek & 141 & 137 & 161 & 159 & 165 \\
elemanlar & Kadın & 261 & 269 & 306 & 319 & 320 \\
\hline Hizmet ve satış elemanları & Erkek & 412 & 440 & 453 & 476 & 580 \\
& Kadın & 265 & 311 & 333 & 340 & 413 \\
\hline Nitelikli tarım, ormancılık ve su ürün- & Erkek & 21 & 18 & 21 & 19 & 17 \\
lerinde çalıșanlar & Kadın & 2 & 1 & 1 & 2 & 2 \\
\hline Sanatkârlar ve ilgili işlerde çalışanlar & Erkek & 377 & 386 & 416 & 393 & 590 \\
& Kadın & 42 & 43 & 47 & 42 & 41 \\
\hline Tesis ve makine operatörleri ve mon- & Erkek & 252 & 281 & 278 & 267 & 417 \\
tajcılar & Kadın & 19 & 28 & 25 & 20 & 25 \\
\hline Nitelik gerektirmeyen işlerde çalışan- & Erkek & 332 & 335 & 321 & 336 & 500 \\
lar & Kadın & 168 & 185 & 237 & 254 & 317 \\
\hline
\end{tabular}

Kaynak: TÜIK, İşgücü İstatistikleri - 2018 (Bin kişi) 
Tablo 7'de yönetici kadrosunda aranılan elemanlarda erkeklerin kadınlardan daha fazla olduğu görülmektedir. Kadınların genel olarak temizlikçi, büro işçiliği vb. geri hizmetlerdeki kadrolara yerleştirilmek istendiği görülmektedir. Geleneksel yapıda olan ailelerde kadın çalışması eğer erkeğin desteğe ihtiyacı var ise uygun görülmektedir. Aileler kız çocukları için üniversite bölümü seçerken mesleklerinin çalışma saatlerinin gündüz ile sınırlı olması, nöbete dayalı olmaması, arazide çalıșmayı gerektirmemesi, fiziksel olarak yorucu olmamasını göz önünde bulundurmaktadırlar.

Tablo 7. İstihdam Edilenlerin Yıllar ve Cinsiyete Göre Íktisadi Faaliyet Kolları

\begin{tabular}{|c|c|c|c|c|c|c|c|}
\hline \multicolumn{8}{|c|}{ İstihdam edilenlerin yıllar ve cinsiyete göre iktisadi faaliyet kolları } \\
\hline & & & 2014 & 2015 & 2016 & 2017 & 2018 - Aralık \\
\hline \multirow[t]{2}{*}{ Tarım } & \multirow{2}{*}{$\begin{array}{l}\text { Tarım, ormancılık ve } \\
\text { balıkçlık }\end{array}$} & Erkek & 2937 & 2956 & 2920 & 2993 & 2797 \\
\hline & & Kadın & 7689 & 8058 & 8312 & 8729 & 8774 \\
\hline \multirow[t]{6}{*}{ Sanayi } & \multirow{2}{*}{$\begin{array}{l}\text { Madencilik ve taş } \\
\text { ocakçılığı }\end{array}$} & Erkek & 130 & 116 & 120 & 131 & 128 \\
\hline & & Kadın & 3 & 3 & 4 & 7 & 7 \\
\hline & \multirow[t]{2}{*}{ İmalat } & Erkek & 3727 & 3752 & 3708 & 3728 & 3768 \\
\hline & & Kadın & 1209 & 1204 & 1207 & 1241 & 1289 \\
\hline & \multirow{2}{*}{$\begin{array}{l}\text { Elektrik, gaz, buhar, su } \\
\text { temini ve kanalizasyon }\end{array}$} & Erkek & 222 & 233 & 229 & 247 & 249 \\
\hline & & Kadın & 23 & 23 & 28 & 30 & 32 \\
\hline \multirow[t]{2}{*}{ İnşaat } & \multirow[t]{2}{*}{ İnşaat } & Erkek & 1832 & 1843 & 1904 & 2013 & 1546 \\
\hline & & Kadın & 79 & 71 & 83 & 82 & 69 \\
\hline \multirow{26}{*}{$\begin{array}{l}\text { Hiz- } \\
\text { metler }\end{array}$} & \multirow{2}{*}{$\begin{array}{l}\text { Toptan ve perakende } \\
\text { ticaret }\end{array}$} & Erkek & 2797 & 2827 & 2866 & 2973 & 2951 \\
\hline & & Kadın & 789 & 865 & 892 & 961 & 1016 \\
\hline & \multirow[t]{2}{*}{ Ulaştırma ve depolama } & Erkek & 1039 & 1023 & 1073 & 1123 & 1126 \\
\hline & & Kadın & 80 & 85 & 112 & 112 & 134 \\
\hline & \multirow{2}{*}{$\begin{array}{l}\text { Konaklama ve yiyecek } \\
\text { hizmeti faaliyetleri }\end{array}$} & Erkek & 1073 & 1132 & 1127 & 1151 & 1132 \\
\hline & & Kadın & 278 & 317 & 344 & 372 & 379 \\
\hline & \multirow[t]{2}{*}{ Bilgi ve iletişim } & Erkek & 172 & 187 & 186 & 197 & 177 \\
\hline & & Kadın & 55 & 64 & 62 & 61 & 50 \\
\hline & \multirow{2}{*}{$\begin{array}{l}\text { Finans ve sigorta faali- } \\
\text { yetleri }\end{array}$} & Erkek & 162 & 157 & 168 & 156 & 158 \\
\hline & & Kadın & 139 & 137 & 132 & 115 & 104 \\
\hline & \multirow{2}{*}{$\begin{array}{l}\text { Gayrimenkul faaliyet- } \\
\text { leri }\end{array}$} & Erkek & 174 & 174 & 199 & 228 & 246 \\
\hline & & Kadın & 31 & 38 & 43 & 58 & 54 \\
\hline & \multirow{2}{*}{$\begin{array}{l}\text { Mesleki, bilimsel ve } \\
\text { teknik faaliyetler }\end{array}$} & Erkek & 434 & 449 & 507 & 547 & 524 \\
\hline & & Kadın & 250 & 302 & 339 & 349 & 403 \\
\hline & \multirow{2}{*}{$\begin{array}{l}\text { İdari ve destek hizmet } \\
\text { faaliyetleri }\end{array}$} & Erkek & 767 & 855 & 928 & 1043 & 599 \\
\hline & & Kadın & 386 & 435 & 469 & 508 & 361 \\
\hline & \multirow{2}{*}{$\begin{array}{l}\text { Kamu yönetimi ve sa- } \\
\text { vunma }\end{array}$} & Erkek & 1164 & 1200 & 1203 & 1185 & 1537 \\
\hline & & Kadın & 219 & 241 & 250 & 277 & 411 \\
\hline & \multirow[t]{2}{*}{ Ĕ̆itim } & Erkek & 674 & 702 & 758 & 732 & 812 \\
\hline & & Kadın & 646 & 708 & 849 & 876 & 1082 \\
\hline & \multirow{2}{*}{$\begin{array}{l}\text { İnsan sağlığı ve sosyal } \\
\text { hizmet faaliyetleri }\end{array}$} & Erkek & 318 & 326 & 328 & 336 & 444 \\
\hline & & Kadın & 653 & 726 & 795 & 850 & 1005 \\
\hline & \multirow{2}{*}{$\begin{array}{l}\text { Kültür, sanat, eğlence, } \\
\text { dinlence ve spor }\end{array}$} & Erkek & 103 & 117 & 107 & 113 & 127 \\
\hline & & Kadın & 29 & 32 & 35 & 41 & 53 \\
\hline & \multirow{2}{*}{$\begin{array}{l}\text { Diğer hizmet faaliyet- } \\
\text { leri }\end{array}$} & Erkek & 516 & 512 & 560 & 566 & 558 \\
\hline & & Kadın & 284 & 281 & 284 & 317 & 327 \\
\hline
\end{tabular}

Kaynak: TÜiK, İsgücü İstatistikleri - 2018 (Bin kişi)

Profesyonel meslek gruplarında; kız çocukları için öğretmen, doktor, hemşire, büro personeli, iç mimar, avukat gibi meslekler daha çok uygun gö- 
rülmektedir. Blackstone’a (2003, s.337) göre; işyerlerinde kadınların ve erkeklerin cinsiyetlerine göre farklı roller üstlenmeleri kendilerinden beklenmektedir.

"Sosyalleşme süreci boyunca kız çocukların uysal, yumuşak ve özverili; erkek çocukların ise yarıșmacı, atak ve girişken olma davranışları pekiştirilmektedir. Muhtemelen bu eğitim farkı, kız çocuk ve erkek çocukların yöneldikleri serbest etkinlik türlerini ve dolayısıyla gizil güçlerini geliştirebilecekleri alanları, daha da ileride meslek seçimini ve meslek yaşamlarını etkilemektedir"(Kuzgun ve Sevim, 2004, s.16).

Kadınlar genel olarak çalışma şartları, analık izinleri, iş güvencesinin özel sektöre göre daha sistemli işlediği kamu sektörünü tercih etmektedirler. Kadınlar yüksek statüde çalışabildikçe iş hayatında kadınlarla ilgili daha fazla düzenlemeler yapıldığı görülmektedir.

Tablo 8 incelendiğinde; tarım, ormancılık, hayvancılıkta kadın çalışanların erkek çalışanlardan daha fazla olduğu görülmektedir. Bunun nedeni kırsal bölgelerde erkekler dışarı işlerinde çalışırken, kadınların kayıt dışı çalışan olarak bu alanlara yönelmesidir. Yıllar bazında çalışan kadın sayısı artarken çalışan erkek sayısı düşmektedir.

Sanayi ve hizmet sektöründe ise yoğun bir şekilde erkek işgücü istihdamı gerçekleşmektedir. Hizmet sektöründe eğitim ve insan sağlığı ve sosyal hizmet faaliyetlerinde kadınların daha çok çalıştı̆̆ görülmektedir. Cinsiyete göre iktisadi faaliyet kolları incelendiğinde ise kadınların cinsiyet rollerine göre istihdam edildiği görülmektedir.

Tablo 8 'te istihdam edilenlerin yıllar ve cinsiyete göre iktisadi faaliyet kolları analiz edildiğinde; erkeklerin en yoğun olduğu, kadınların daha az istihdam edildiği mesleklerin başında aşağıdakiler gelmektedir:

- Madencilik ve taş ocakçılığı,

- Elektrik, gaz, buhar, su temini ve kanalizasyon,

- İnşaat,

- Bilgi ve iletişim,

- Ulaştırma ve depolama,

- Kamu yönetimi ve savunma,

- Kültür, sanat, eğlence, dinlence ve spor

Bu meslekler fiziksel yeterlilik ve bedensel güç gerektirmesinden ötürü kadınlara uygun görülmemektedir.

\section{ÇALIŞMA YAŞAMINDA KARŞILAŞILAN SORUNLAR}

Kadınlar çalışma yaşamına girdiklerinde aile - iş dengesi kuramama, cinsiyet ayırımcılı̆̆ı, taciz, gebelik durumu ve analık halinden dolayı işverenin ön yargılı olması gibi nedenlerden dolayı sorun yaşarlar.

Kadınlar ev yaşantılarındaki rutin işleyişi her zaman devam ettirmek zorundadır. Sabah kahvaltı hazırlamak, çocukların okula gitmesine yardımcı ol- 
mak, okul sonrası çocukların okuldan alınması, var ise kurslara ulaşımın sağlanması, evdeki yaşlı - hasta insanın bakımı, evin temizlenmesi, akşam yemeği hazırlanması vb. işler kadınların sorumlulukları olarak görülmektedir. Kadının iş hayatına girebilmesi için bu sorumlulukları aksatmayacak şekilde yerine getirmesi gerekmektedir ya da bu sorumlulukları paylaşacak bir eş veya yardımcının varlığı gerekmektedir.

Önder'e (2013, s.43) göre çalışma saatlerinin kadının ev işleri aksatmayacağı şekilde düzenleyebilmesini sağlayan esnek çalışma, evli ve çocuklu kadınların işgücüne katılım oranının artmasını sağlamıștır. Ayrıca Önder (2013, s.44); kısmi çalışma, uzaktan çalışma gibi esnek çalışma modellerinin kayıt dıșllığı azalttığı gibi kadınların iş hayatından kopmalarının önüne geçeceğine vurgu yapmıştır.

İmalathane, hastane, turizm işletmeleri, havacılık sektörü, bar ve restoran, çamaşırhane, benzin istasyonları vb. işyerlerinde gece çalışılması yapılmaktadır. Ülkemizde geleneksel aile yapısında yaşayan aileler için gece çalışması yapılan bu türde işyerleri kadın çalışmasına uygun değildir.

Kadınların çalışmasına engel olan faktörlerin başında evde yaşlı, hasta, çocuk bakmak zorunda olmaları ve bu bireyleri birakacak bir yer olmaması, kreş ve bakım evinin ücretlerinin kadının gelirini anlamsızlaştıracak kadar yüksek olması, ulaşılabilirliğin pratik olmaması gelmektedir.

Çalışma yaşamında ayrımcılık cinsiyet ayrımcılığı, yaş ayrımcılığı, ırk ayrımcılığı, farklı coğrafyada yetişmeden dolayı oluşan kültürel ayrımcılık, siyasi ayrımcılık, ekonomik ayırımcılık olarak karşımıza çıkmaktadır. Cinsiyet ayrımcılığı kadını doğrudan etkilemektedir. Toplumsal algı nedeniyle insanlar işleri ve meslekleri erkeğe uygun iş ve meslekler; kadına uygun iş ve meslekler olarak sınıflandırmıștır. Kadınlar her zaman doğaları gereği öğretmen, hemşire, sekreter, temizlik görevlisi, mutfak elemanı bakım işleri gibi işlerde çalıştırılmak istenmektedir. Kadınlar bu mesleklerde yönetici konumuna gelememekte ve alt sınıf çalışanı olarak kalmaktadır. Bu durum kadınların yönetimde söz sahibi olmayan pasif işgücü olmalarına neden olmaktadır.

Kadınlar işgücü piyasasında dezavantajlı grup olarak kabul edilmektedir. $\mathrm{Bu}$ durum kadınların dışlanmışlığının bir göstergesidir. İstihdamda cinsiyete dayalı fırsat eşitliğinin olmaması kadınların çalışma yaşamına girişini zorlaştırmaktadır. Yılmaz ve Zoğal'a (2015, s.6) göre; cinsiyet ayrımcılığından ötürü kadınlar çalışma yaşamı faaliyetlerine tam olarak katılamamakta, kamusal olanaklardan faydalanamamakta, sağlıksız koşullarda çalışmakta, işyerinde haksızlığa ve tacize uğramakta ve karar mekanizmalarında yer alamamaktadırlar.

Oğuz ve Kan (2001, s.1); toplumun sosyal, kültürel ve ekonomik açıdan gelişmesi için cinsiyet ayrımcılığında dengeli bir yaklaşımın olması gerektiğini, toplumu oluşturan bütün bireylerin tüm olanaklara eşit bir şekilde ulaşması gerektiğini vurgulamışlardır. Kadınların çalışma yaşamına dâhil olabilmeleri ve çalışma yaşamından kopmamaları için cinsiyet ayrımcılığının son bulmasının yanı sıra kadın istihdamını destekleyici çalışmalar yapılmalıdır. 
19 Temmuz 1967 'de Türkiye'de yürürlüğe giren İLO 100 No'lu Eşit Ücret Sözleşmesi (1951) erkek ve kadınların, eşit işlerde eşit ücret ve sosyal haklara sahip olması gerektiğini vurgulamaktadır.

ILO' nun 111 No'lu Ayrımcllık (İş ve Meslek) Sözleşmesi'nde Madde 1'de Ayırım deyimi;" Irk, renk, cinsiyet, din, siyasal inanç, ulusal veya sosyal menşe bakımından yapılan iş veya meslekte tabi olunacak muamelede eşitliği yok edici veya bozucu etkisi olan her türlü ayrllı gözetme, ayrı tutma veya üstün tutmayı, ilgili üye, memleketin, varsa temsilci, iş ve işveren teşekkülleri ve diğer ilgili makamlarla istişare etmek suretiyle tespit edeceği, meslek veya iş edinmede veya meslekte tabi olunacak muamelede eşitliği yok edici veya bozucu etkisi olan bütün diğer ayrılık gözetme, ayrı tutma veya üstün tutmayı ifade eder. " olarak geçmektedir (ILO Sözleşme Maddesi).

ILO'nun Dünya'da İstihdam ve Sosyal Görünüm- Eğilimler 2018 Raporuna göre; kadınların işgücü piyasasına katılması erkeklere göre daha az muhtemeldir. Kadınların \%26'sı istihdama katılmada küresel bir cinsiyet ayrımcllığıyla karşı karşıya kalmaktadır (ILO, 2018, s.2). Ekonomik kalkınma ve yoksullukla mücadele için toplumsal cinsiyet eşitliği farkındalığının önemi günümüzde artmış ve işgücü piyasasında kadınların her zamankinden eğitimli ve katılımcı olması önem kazanmıştır (ILO, 2018, s.5). İşgücü piyasasında işin niteliği ile ilgili sorunlara rağmen, işsizlik ve cinsiyet eşitsizliği küreseldir ve bunların karakteri ve önceliği ülkelerin gelişmişlik seviyelerine göre değişmektedir (ILO, 2019, s.2).

Avrupa Parlamentosu Vatandaşların Hak ve Anayasa İşleri Politikalar Birimi'nin Avrupa Birliği'ndeki Genç Kadınların İşsizliği ile ilgili 2017'de yayınladığı rapora göre genç kadınlar erkeklere göre daha fazla yarı zamanlı, geçici işlerde çalıștırılmaktadır ve düşük maaş alma olasılıkları daha yüksektir. Aynı raporda cinsiyet farklılığının genç erkeklerde ve genç kadınlarda istihdam edilmede değişik şartların oluşmasına neden olduğu, eğitim ve çalışma yaşamında uzlaştırma politikaları için etkili tasarılara ihtiyaç duyulduğunun üstünde durulmuştur. TÜİK verilerine göre; ne eğitimde ne istihdamda olan gençlerin oranı genç erkeklerde \%15,6, genç kadınlarda ise \%33,6'dır (http://www.tuik.gov.tr/PreHaberBul-tenleri.do?id=30723). Bu veri genç kadınların erkeklere göre başka bir dezavantajlı durumunu göstermektedir.

Çalışma yaşamında işyerinde yaşanan fiziksel ve psikolojik şiddet her çalışanın karşılaşabileceği bir sorundur. Baypınar' a (2003) göre kişiye yöneltilen istenmeyen eylem, söz, davranış, kişiye rahatsızlık verebilecek ima, cinsiyete yönelik gerçekleștirilen yaklaşımlar, çalışana küçük düşürücü görevler vermek ahlak ve iyi niyete aykırı olan tutumlar psikolojik şiddet olarak tanımlanabilir.

Toplumumuzda genel olarak aile içinde, sosyal alanlarda ve iş yaşantısında kadınların erkeklerden daha güçsüz olduğu düşüncesi yaygındır. Einarsen (2000, s.386) erkeklerin, erkekler tarafından zorbalığa uğrarken; kadınların hem erkekler hem kadınlar tarafından zorbalığa uğradığını belirtmiștir. Kadınlar her türlü şiddeti, doğası gereği daha etkili ve zor yaşarlar. 
İşyerinde yaşanan psikolojik şiddet kadının işe tutunmasına engel olabilmektedir. Yaşanacak en ufak bir taciz vakası ise kadını işten kopartmaktadır. İşyerinde şiddet, zorbalık, taciz içerikli davranışlara maruz kalan kadınların sosyal yaşamlarında bu etkiden kurtulmaları çok daha zordur.

Yaşanan psikolojik şiddet; taciz, ylldırma, zorbalık şeklinde gerçekleşebilir. İşyerinde yaşanan rekabet ortamında güç eşitsizliği içinde olan çalışanlardan güçlü olan kişi zayıf olana şiddet eğilimi gözlenebilmektedir. Güç eşitsizliği içinde yaşanan şiddet genel olarak güçlü olanın pozisyonu gereği sağlam olan konumuna güvenerek görevini kötüye kullanması ve mağdur olan kişinin işe ihtiyacı olması, güçsüz olmasından kaynaklanır. Üstlerden gelen taciz iş güvencesi, terfi, eğitim imkânları, çalışma ortamının ayarlanması, iş yükünün belirlenmesi gibi iş yaşantısına doğrudan yansıyacak kararları etkileyeceğinden mağduru çok zor durumda bırakır. Kişi davranışa maruz kalmaya boyun eğmek ya da iş yaşantısını doğrudan etkileyecek kararları kabullenmek arasında kalabilmektedir.

İşyerlerinde genel itibari ile güçsüz, işten çıkarılma potansiyeli yüksek, çalışmak zorunda olan, çaresiz ve savunmasız kişiler şiddet ve tacize maruz kalmaktadır. Einarsen (2000, s.386) şiddet ve tacizin erkek egemen; büyük özel şirketler ve sanayi işyerlerinde daha fazla görüldüğünü savunmaktadır. Baypınar (2003) toplumumuzda genel olarak 30 yaş altında, bekâr, dul, ayrı yaşayan, iş hayatına sonradan girmiş tecrübesiz olan, herhangi bir sendikaya bağlı olmayan, sosyal yașantısında bakmakla yükümlü olduğu kișiler olan, ișe çok ihtiyacı olanlar şiddet, zorbalık ve tacize maruz kaldığını belirtmiştir.

\section{SONUÇ}

Kadınların çalışma yaşamında yaşadıkları sorunlar, binlerce yıldır olagelen ataerkil sistemin toplumda kadınlar hakkındaki oluşturduğu algılardan meydana gelmektedir. Berktay'a (2015) göre kadınlar eş - anne rolünde kutsallaştırılmış, olumlu davranışlar ve rollerle bağdaştırılmıştır. Günümüzde kadın evinde, toplumsal çevresinde, çalışma yaşamında ataerkil sistemin kendisine dayattığı daima ikincil konumda kalma durumundan kaynaklı birçok sorun yaşamaktadır.

Kadınlar ev eksenli olan temizlik görevlisi, büro işçisi vb. mesleklerde veya analık rolü ile bağdaşan sabır ve şefkatli olmayı gerektiren öğretmen, sağlıkla ilgili meslekler de tercih edilmektedir. Çocuklar öğrenim sırasında yeteneklerine göre alanlara yönlendirilmeli, cinsiyete göre meslek seçimi yaptırılmamalıdır. Bu kapsamda projeler geliştirilmeli bu kapsamda halkın rahatlıkla katılım sağlayabileceği eğitimler verilmelidir.

Kadın istihdamının düşük olduğu bölgeler belirlenip, işyerlerine çalışan sayısına göre belli bir oranda kadın çalıștırma zorunluluğu getirilmesi konusunda yasal düzenlemeler yapılması kadın istihdamına katkıda bulunacaktır. Bu düzenlemeler her ne kadar kadının güçsüz ve dezavantajlı olduğunu ka- 
bul edildiğinin bir göstergesi gibi görünse de onları olumlu yönde etki edecektir. Ayrıca kadın çalışanlara yönelik esnek çalışma planlarının düzenlenmesi, kreş yardımları vb. kadını destekleyici uygulamalar arttırılmalı ve daha çok kadının bu imkânlardan faydalanması sağlanmalıdır. İşgücü piyasasında cinsiyete dayalı olarak mesleklerin sınıflandırılması kadının belli mesleklere yönelmesine sebep olmaktadır. Bu durum onlar için dezavantajlı bir durumdur. Kadın böylelikle emek yoğun ve düşük ücretli mesleklerde çalışmak zorunda kalmaktadır. Bu durumun başlıca nedeni kız çocuklarının eğitim olanaklarına erkekler kadar rahat ulaşamamasından kaynaklanmaktadır. Bu sebeple kız çocuklarının eğitimden daha etkin ve daha uzun süreli yararlanması sağlanmalıdır. Bunun için ailelere bunun gerekli olduğu seminerler, toplantılar düzenlenmeli; kamu spotları hazırlanmalı, sosyal medyada etkin olarak takip edilen kişilere ulaşılarak onların konuya dâhil edilmesi ve mesaj vermede desteğin sağlanması, gazete ve dergilerde reklamların verilerek toplumsal bilincin geliştirilmesi sağlanmalıdır.

\section{KAYNAKÇA}

Ansal, H. (1996). Yeni teknolojiler ve kadın istihdamı. Women's Studies Reviev, 4, 55-72.

Baypınar, B. (2003). İşyerinde cinsel taciz. İş, Güç Endüstri İlişkileri ve İnsan Kaynakları Dergisi, 5(2), 137-144.

Berktay, F. (2015). Tarihin cinsiyeti. İstanbul: Metis Yayınevi.

Berktay, F. (2012). Tek tanrılı dinler karşısında kadın. İstanbul: Metis Yayınevi.

Blackstone, A. M. (2003). Gender roles and society, The universty of maine digitalcommons@umaine, sociology school faculty scholarship, 8, 335-338. Santa Barbara.

Demiryontan Tura, N. ve Savran Acar G. (2016). Kadının Görünmeyen Emeği. İstanbul: Yordam Kitap.

Einarsen, S. (2000). Harassment and bullying at work: A review of the scandinavian approach. Aggression and Violent Behavior, 5(4), 379-401.

Erkek, S. ve Karagöz. H. (2009). Kadının iş hayatındaki yeri ve karşılaştığı sorunlar. Konya: Konya Ticaret Odası Etüd - Araștırma Servisi.

Foucault, M. (2007). Cinselliğin tarihi. (Çev. H. Uğur Tanrıöver). İstanbul: Ayrıntı Yayınları.

ILO (Uluslararası Çalışma Örgütü). 100 No'lu Eşit Ücret Sözleşmesi. https://www.ilo.org/ankara/conventions-ratified-by-turkey/WCMS_377269/lang--tr/index.htm (erişim tarihi: 14.04.2019).

ILO (Uluslararası Çalışma Örgütü). 111 No'lu Ayrımcılı (İş ve Meslek) Sözleşmesi. https://www.ilo.org/ankara/conventions-ratified-by-turkey/WCMS_377273/lang--tr/index.htm (erişim tarihi: 14.04.2019).

ILO (Uluslararası Çalışma Örgütü). Eşitlik ve Ayrımcılık. https://www.ilo.org/ankara/areas-of-work/equality-discrimination/lang--tr/index.htm (erişim tarihi: 14.04.2019).

Kocacık, F., ve Gökkaya V. B. (2005). Türkiye'de Çalışan Kadınlar ve Sorunları. C.Ü Íktisadi ve Ídari Bilimler Dergisi, 6(1), 195-219. 
Kuzgun, Y., ve Sevim A, S. (2004). Kadınların çalışmasına karşı tutum ve dini yönelim arasındaki ilişki. Ankara Üniversitesi Eğitim Bilimleri Fakültesi Dergisi, 37(1), 14-27.

Oğuz C. Ve Kan A. (2001). Konya ili Seydişehir ilçesi Yaylacık köyünde bahçe tarımında kadınların rolü ve etkinliğinin ölçülmesi. Selçuk Üniversitesi Ziraat Fakültesi Tarım Ekonomisi Bölümü Araştırması, Konya.

Önder, N. (2013). Türkiye'de kadın işgücünün görünümü. Çalışma ve Sosyal Güvenlik Bakanlığı Calıșma Dünyası Dergisi, 1(1), 35-61.

Özsoy, E. (2003). Kalkınma - yoksulluk ikilemi ve Türkiye. IŞ, GÜÇ - Endüstri İlişkileri ve İnsan Kaynakları Dergisi, 5(1), https://www.isguc.org/?p-=article\&id=44\&cilt=5\&sayi=1\&yil=2003 (erişim tarihi:09.07.2019).

Parlaktuna İ., (2010). Türkiye'de cinsiyete dayalı mesleki ayrımcılığın analizi. Ege akademik Bakış, 10(4), 1217-1230

Platon Devlet. (Çev. Sentez Grafik Servisi). İstanbul: Sentez Yayınları.

Policy Department For Citizens' Rights And Constitutional Affairs, (2017). Young Women's Unemployment in EU; Briefing 2017

Sautet M. (1998). Kadınların özgürleşmesi üzerine. (Çev. S.Serdaroğlu). İstanbul: Telos Yayıncillk.

TUIK (2018). http://www.tuik.gov.tr/PreHaberBultenleri.do?id=30707 http://www.tuik.gov.tr/PreHaberBultenleri.do?id=30723 TUIK, İşgücü İstatistikleri, 2018

UNICEF (Birleşmiş Milletler Çocuklara Acil Yardım Fonu ) https://www.unicef.org/turkey/pr/_ge6.html , ( erişim tarihi: 27.03.2019).

Yaraman, A. http://www.aysegulyaraman.com/makale/yanilsamanin-_neresindeyiz.pdf

http://www.tekgida.org.tr/Dosya/BilgiDosya-

lari/Tekg\%C4\%B1da_i\%C5\%9FKadinRaporu.pSd. Serbestlik Derecesi (erişim tarihi: 22.04.2019).

Yılmaz M. ve Zoğal Y. (18-20 Ağustos 2015). "Kadının İşgücüne Katılımının Tarihsel Gelişimi ve Kadın İstihdamını Etkileyen Faktörler: Türkiye ve Avrupa Örneği”.EconWorld2015@Torino, Italy. 